\title{
The Sequence of Loyalty and Filial Piety and Its Ideological Origins in the Traditional Ethical Culture of China and Japan
}

\author{
Weiyu Yang \\ (Zhongkai University of Agriculture and Engineering, Guangzhou \& Guangdong University of Foreign \\ Studies, Guangzhou; y95719@qq.com) \\ ORCID: 0000-0003-4935-1410
}

\section{Introduction}

During the thousands of years from the Taika Reform that comprehensively studied the law system of the Tang Dynasty in China in the $7^{\text {th }}$ century to the modernization of the Meiji Reform in the $19^{\text {th }}$ century, traditional Japanese culture had been deeply influenced by Chinese Confucian culture. Traditional Japanese culture showed an obvious characteristic of "Tangization", which mistakenly gives people an illusion that both traditional Japanese culture and traditional Chinese Confucian culture belong to the same type of East Asian culture and that traditional Japanese culture is an exotic flower growing on the Japanese soil out of traditional Chinese Confucian culture. If we respectively delve into the core spirit of these two cultures from their similar layers of surface, we would find the specificity of these two cultures. Be it the "Tangized Japan" in history or the "Europeanized Japan" since the Meiji period, Japan has still been mainly dominated by the spirit of "Yamatodamashii" that got its form from the "mono no aware" tradition, the Shintoism and Bushido during the Edo period, which were "prototypes" not possessed by traditional Chinese Confucian culture itself. Among many differences in the subject consciousnesses of these two cultures, there is one difference that has attracted the attention of scholars, i.e. the sequence of loyalty and filial piety at the core of their spiritual cultures. Inazo Nitobe, the Bushido scholar who first introduced the western world to Japan, believed that "in China, Confucianism regards obedience to parents as the top obligation, whereas in Japan, loyalty is the priority" (Inazo Nitobe 1993), which showed that modern Japanese scholars had a knowledge of the cultural heterogeneity between China and Japan and a self-consciousness of local culture. At the end of last century, when analyzing the psychological structure of the Chinese culture and the Japanese culture, Li Zehou (2008) further explicitly pointed out that "filial piety' is at the core of the five cardinal relations 
of China while in Japan, the social order is based on "loyalty to the emperor" (deities). The former is very concrete, secular, limited and relatively free in terms of the targets, scope and relationship while the latter is more abstract, transcendental, infinite and very rigid. " That is to say, both cultures give emphasis on the values of "loyalty" and "filial piety", but Confucian culture emphasizes that "filial piety" comes first, "benevolence" lays the foundation and "filial piety" serves as the root of "benevolence". As was said in The Analects of Confucius, "It is rare to find those filial to parents and obedient to elderly brothers would like to offend the rulers. It is unlikely to find those who do not like to offend the rulers would rise in rebellion. When a gentleman is devoted to fundamental affairs, he would establish the principles of governing the country and behaving oneself. Filial piety to parents and obedience to elderly brothers is the root of benevolence." However, it is a different case in Japan. Although traditional Japanese culture also advocates loyalty and filial piety, "loyalty" is absolutely the first value and it is in preference to the ideology and value orientation of "filial piety", which is most obviously reflected in its being regarded as the backbone of Japan's ethical spirit and part of the concept of Bushido that symbolizes "Yamato-damashii" (Japanese Spirit). Besides, loyalty, internalized as an ideological consciousness and a behavioral guideline for general public, becomes one of the important proofs of the particularity of traditional Japanese culture. Then, why is "filial piety" the priority in the value orientation of traditional Confucian culture and why does traditional Japanese culture regard "loyalty" as the foundation and have "loyalty" in precedence to "filial piety" in traditional Japanese culture especially in the transmutation of Japanese Bushido? Which factors influence or determine the value orientation of Bushido? This is an interesting cross-cultural topic worth exploring.

\section{"Loyalty" in Two Origins of Bushido and Its Connotations}

As is known to all, the samurai class in Japan came into being in the middle of the $9^{\text {th }}$ century. They were originally family slaves who served the noble class and mainly engaged in house keeping and property management. Like the noble class, the samurai class was also hereditary. By the $12^{\text {th }}$ century, the force of the samurai class had been able to share power with the aristocratic regime led by the emperor, which was the so-called two-headed politics. By the $17^{\text {th }}$ century, in the era of the Edo Shogunate, the samurai regime had been able to completely hold power over the emperor. Over 600 years of ruling by the samurai class from the $12^{\text {th }}$ century to Toubakundou and the Meiji Reform in the $19^{\text {th }}$ century, the "Bushido" in the period, as the moral standard of the samurai class, had the authority of national ideology. Since the samurai class seized power, due to the frequency of wars, the "Bushido" worshipped by the samurais have lacked refined polishing; but in the relatively peaceful era of Edo, the local consciousness of Japanese Bushido began to revive and gradually took its shape, which eventually converged to two 
origins of Bushido ${ }^{1}$. One branch, represented by Yamaga Sokou (1622-1685) and Yoshida Shoin (1830-1859), was deeply influenced by Chinese Confucian ethical thoughts, so it was called Confucian Bushido or Shido; the other branch, represented by Yamamoto Tsunetomo (1659-1719), advocated Japan's samurai ethics and styles in the period of the Warring States with obvious local characteristics and "Japanological" colors and its representative work was Hagakure Kikigaki. This branch represents "antique Bushido" or "tradition dedicated to morality", so it was called Hagakure Bushido. Because it was peaceful in the era of Edo, the Tokugawa Shogunate that gradually became bureaucratic practiced Confucianism, and Confucian Bushido became the mainstream. However, the influence of the Confucian Bushido gradually disappeared after the period of Warring States, while the influence of the Hagakure Bushido gradually increased with the uproar of militarism.

Hagakure Bushido advocates "loyalty to the emperor and devotion to public interests" and this type of "loyalty" to the emperor is not attached with any conditions. It is the moral ideal and highest honor for samurais to "sacrifice their lives" for the emperor. "With regards to Bushido, in a word, it is essential to serve the emperor at all costs. This is the basic thing" (Yamamoto Tsunetomo 2014, 60).

Speaking of the "loyalty" of Bushido, it is inevitable to mention how Bushido views "death". As has been pointed out by some scholars, "death" is not a moral item, but it has a lot to do with morality. Especially in Japanese Bushido, how to understand "death" is a core issue (Tang Liguo 2010,122). It could be said that the disemboweling, selfmutilation and kaishaku of samurais in modern Japan and even the so-called "gyokusai" of Japanese soldiers in World War II were obviously penetrated with the consciousness of "death aesthetics" that could not be found in the mainstream of other exotic civilizations, i.e. viewing death from a perspective of aesthetics. As was said in the beginning of the Hagakure Kikigaki, "Bushido implies death, and it does not lead to anything else except death. When a samurai is dying, he should choose to give up his life unstintingly. A samurai should march forward bravely with the awareness that he is bound to die. A samurai should rectify their mind every day and night, think about the true meaning of death, choose to face up to death and always remain ready to die unflinchingly. In this case, as Bushido and samurais get united as one, samurais could stay away from failure and keep devoted to their duties for a lifetime" (Yamamoto Tsunetomo 2014, 1). It could be seen that this mental cultivation of facing up to death has a profound philosophical connotation of "being toward death" and it is different from "facing death unflinchingly" and "dying for righteousness" held by Confucius and Mencius. Instead, it is an irrational existence that takes neither good nor evil into account, goes beyond calculation, and

1 At present, the understanding of the domestic academic circle about the genealogy of Japanese Bushido is still mostly under the framework of Japanese scholars including Inazo Nitobe, Inoue Tetsujir (1855-1944). Japanese scholars have distinguished two different types of genealogy: Inoue Tetsujir has proposed the genealogy of "Yamaga Sokou-Yoshida Shoin-Meiji" and based on it, Tetsuro Watsuji has proposed the other genealogy of "Kamakura-Warring States-HagakureShowa". 
disregards consequences. It seems to have a sense of zen, which is called "shigurui" by Yamamoto Tsunetomo, i.e. it does not consider the value of death, whether it is heavier than Mount Tai or lighter than a feather. It would be glorious as long as they sacrifice their lives for the emperor and death is not insulting at all. So, how does the Bushido held by the Hagakure school view "filial piety"? There are several references to "filial piety" in Hagakure Kikigaki, which is either placed after "loyalty" or directed toward the understanding of "loyalty". "Every morning when we are offering sacrificial services, we should first worship our emperor and parents, and then worship deities. By placing the emperor in the first place, not only parents would feel delighted, but the deities would also appreciate it" (Yamamoto Tsunetomo 2014,11). By means of "shigurui", the Hagakure Bushido emphasizes the supreme value of "loyalty". Loyalty to the emperor and devotion to public interests is a prerequisite for "filial piety".

Then, how did Confucian Bushido, the major trend at that time, regard "loyalty"? Yamaga Sokou, one of the most famous Confucian scholars and the representative of Confucian Bushido in the era of Edo, attached great importance to "pursuance of truth". Different from claims held by Yamamoto Tsunetomo, Yamaga Sokou did not recognize the meaning of death. With regard to the "shigurui" of samurais, different from Hagakure Kikigaki that prettified "death" to the utmost, Yamaga Sokou advocated that the "pursuance of truth" was necessary in terms of death. He emphasized that "death is easy but success is difficult", namely, "it is easy to choose death while it is difficult to succeed in something", so one should think over whether he should "die" or not, i.e. whether it is "justified or not" to die (Tang Liguo 2010,18). Yoshida Shoin, another famous thinker at the end of the Edo period, disapproved of "people with brute courage" and required samurais to abide by the principle of "not hindering others, not behaving indecorously and not talking exaggeratedly", which was different from the "shigurui" in Hagakure Kikigaki written by Yamamoto Tsunetomo (Tang Liguo 2010, 113).

However, in Yamamoto Tsunetomo's opinion, the more complete the theory of Bushido was, the more ideas would be constructed, and the more entangled samurais were in argumentation, the more far away they were from the true meaning of Bushido. This is exactly the "thin and light Bushido over the wind" that Yamamoto Tsunetomo resented, which was the prevailing practice of Confucian Bushido in the region of Edo. "Bushido advocates going forward, regardless of whether it seems imprudent or not to do so; boldness is the most important thing (Yamamoto Tsunetomo 2014, 53). The "loyalty" of Bushido refers to loyal deeds that simply emphasize the motive without taking consequences into account. Although Confucianism infused Japanese Bushido with the rationality of justice, what is paradoxical about the history is that Confucianism Bushido did not become a major trend that influenced later generations.

To sum up, the understanding of "loyalty" by the Hagakure Bushido represented by Yamamoto Tsunetomo, namely, irrational shigurui and unconditional loyalty to the emperor and devotion to public interests, something that could not be found in traditional 
Confucianism. Its argument is made specific to Confucianism's emphasis on argumentation, thus it is anti-Confucian in essence. In addition, although under the influence of Confucian culture, the Confucian Bushido by Yamaga Sokou and Yoshida Shoin interpreted the connotation of "loyalty" differently from the Hagakure Bushido represented by Yamamoto Tsunetomo in that it absorbed some rational factors of Confucianism and proposed new ideas including "flareback of loyalty" (disobeying the orders of the emperor unflinchingly in order to safeguard the fundamental interests of the emperor). However, there is no doubt that "loyalty" was still esteemed as the highest value by the Confucian Bushido, which was exactly the same to Yamamoto Tsunetomo's interpretation of it. Therefore, in a sense, although "loyalty" of Chinese Confucianism ethics had profoundly influenced Japanese Bushido, it did not touch the spiritual core of Bushido and instead, it ended up being integrated by Bushido.

\section{Differences of Loyalty Principles Between China and Japan and Their Origins}

Confucianism emphasizes "benevolence", which is originated from "filial piety", and "filial piety" precedes "loyalty", this thought has been pervading all things, laying a foundation for the sequence of loyalty and filial piety in the picture of traditional Chinese ethnics. As was mentioned above, Bushido rules other moral items with "loyalty" and "filial piety" is under "loyalty". The understanding of "filial piety" is contained and stipulated by the value of "loyalty" and the status of "loyalty" is similar to that of "benevolence" in the Confucian order of human relations. In the traditional ethics of Chinese culture and Japanese culture, the differences between their sequence of loyalty and filial piety are obvious, which has almost become the basic consensus in the academic circles of China and Japan. But opinions are varied on the interpretation of the differences between the traditional ethics of Chinese culture and Japanese culture. Based on the genealogy of Bushido, this paper interprets the connotation of "loyalty" in Bushido and traces back to its origins with the possibility of finding causes that differ from Chinese Confucianism. The samurais are not only the servants of the emperor but also the masters of the subordinates. Their relationship with the emperor is similar to that between the emperor and his subjects in China but they also are different from each other in a certain way. How should officials deal with the relationship with the emperor? It could be said that in China's pre-Qin Confucianism, loyalty to the emperor was the fundamental principle but the loyalty was also conditional.

Confucius proposed to "serve the emperor according to the doctrines of the Duke of Zhou, if not, he would rather resign" (The Analects of Confucius · Advanced). Confucius advocated seeking the realization of aspiration instead of seeking food. (The Analects of Confucius, Duke of Weiling). In the period of Warring States, Xunzi systematically developed this idea, emphasizing "serving the emperor with propriety in a loyal and 
unyielding manner". The so-called "loyalty" refers to "benefiting the emperor by obeying or disobeying his orders" (Xunzi · Principles of Being an Official). Xunzi also advocated "following the correct principles instead of the emperor". Xunzi believed that officials should not only dare to admonish the emperor, but also dare to resist the orders of the emperor and usurp the power of the emperor so as to stabilize the country and honor the emperor (Xunzi 2012).

Serving the emperor with Confucian doctrines by abiding by the correct principles rather than blindly obeying the emperor. Confucius and Xunzi's doctrines of the relationship between the emperor and officials have a very distinct rationality of the pre-Qin Confucianism. This relatively distinct rational tone of Confucianism is the same to the spiritual system inherited by Confucius, that is, the theological elements in the ideological system of the Western Zhou Dynasty were underdeveloped, so they were related to the tradition of esteeming virtues that emphasized the matching virtue with fate. In the pre-Qin period, Confucianism put more emphasis on the humanity rather than on the deities. As was stated by Confucius, "Confucius never talks about ghosts or gods", "how can we serve ghosts and gods when we are not ready to serve other people", "when offering sacrifices to ancestors, it is as if the ancestors were there; when offering sacrifices to gods, it is as if the gods were there", so he never denied the existence of gods. In this sense, Confucianism does not have a strong religious color, so it is not a religion, and the mysticism of the religion and the principle of asking followers to "respect unconditionally" cannot be implemented in the application of the Confucianism ethics in daily life (Han Dongyu 2004). However, this is not same the case in Japan. With the religious background of Shinto and the Tennoism supported by Shinto, the moral item of "loyalty" takes on a mysterious religious color obtains absolute authority that cannot be questioned, which will be discussed later.

The reasons why Bushido regards "loyalty" as the highest value are as follows. First of all, from the perspective of reality, it can be interpreted as requiting the favors of the emperor under the feudal system of personal attachment, i.e. as the emperor has done favors for the samurai, the samurai is willing to repay it with his life, and there are no any other misgivings. "Favor" is manifested as the hereditary support and salaries provided by the emperor to the samurai so as to guarantee his life. Therefore, the nature "loyalty" is the emperor-subordinate relationship based on economic conditions with a color of utilitarianism.

Second, the ethical order of Japan is different from the traditional Chinese Confucianism that gives emphasis on family-centered blood ties. Cored at the filial piety of the son to the father, traditional Confucianism expands this model of blood ties externally in a differential pattern. Therefore, the filial piety is the most fundamental thing as well as the starting point, based on which a model of self-cultivation, family harmony, country management and world peace and an ethical order oriented toward "benevolence" have been developed. However, the ethical order of Japan does not emphasize the connection 
of blood ties as Chinese Confucianism does, and "fictitious kinship", i.e. the no-blood kinship of having the same rights and obligations as relatives of the same blood, has also been widely recognized and it also attaches more attention to the connection of village communities and groups.

Third, from the perspective of the ideological root, "loyalty" is obviously influenced by the local Shintoism. Shintoism, characterized by the appeal to ancient myths and legends, goes beyond right and wrong, beyond good and evil in virtue of images and sensibility. In sacrificial ceremonies, Japanese Shinto not only worshipped such deities that safeguard the well-being of all people and care for the sufferings of all beings as Mother Buddha, the Jade Emperor and Guang Yu, Mazu of the folk religions, but it also worshipped those appalling devils. The indoctrination of Shintoism is characterized by its irrationality and it could not appeal to reason. Instead of resorting to reason, it carries traditional customs and connects national emotions with religious emotions. The gods worshipped by Japanese have the characteristic of natural religion. For gods, there are no differences between right and wrong, good and evil. Amaterasu's irrational "mad" words and deeds and "unscrupulous behavior" recorded in the myths seem to have the characteristic of the Dionysian spirit described by Nietzsche, which had a profound influence on the Bushido in the period of Warring States. In short, there is an allusion to of godly madness in Bushido's "shigurui". Ancient Japanese books such as Kojiki and Nihon Shoki recorded various stories of gods going mad, which showed the irrationality of this type of sacrificial ceremonies. In Hagakure Kikigaki, there are many remarks that go beyond right and wrong, beyond good and evil, and beyond life and death, whose ideological root lies in the ancient Japanese mythology Kojiki (Li Dongjun 2007).

Japan's Shintoism and Tennoism complement each other and imperial ruling equals to godly ruling. Japanese Shinto bases its prototypes on nature worshipping, ancestral worshipping and emperor worshipping. The emperor is not only the descendant of Amaterasu and but he also represents Amaterasu in the earthly word. The emperor himself is the god. To this day, the emperor has still been a taboo subject that people can not freely talk about. As the state system, the Shintoism-Tennoism system under the eternal ruling of a single imperial family has obvious religious characteristics and the "loyalty" to the emperor has the "devoting spirit" and "unconditional respect" required by the religion. This kind of "loyalty" is abstract and unconditional beyond utilitarianism.

Chinese people also talk about "loyalty", but there is a prerequisite to their "loyalty", i.e. "if the emperor is unruly to officials, then he will be offended by officials", but "if the emperor treats officials with propriety, then he would be repaid with loyalty." So it is a relationship of two-way choice. In other words, the "loyalty" is a relative one with conditional obedience. However, in Japan, "although the emperor is unruly to officials, officials could not be disobedient to him". So, the "loyalty" in Japan is an absolute one with unconditional obedience. In this sense, although the "loyalty" of the traditional Confucianism and the "loyalty" of the Japanese Bushido are similar in their forms, they have 
different connotations so far as to say that the "loyalty" of Bushido is anti-Confucianism at the spiritual core. This is because of the absoluteness and irrationality of the "loyalty" of Bushido, which was called "madness" in Hagakure Kikigaki. Therefore, it is different from the "loyalty" of the Confucianism constraint by reason and truth. "Loyalty" should not only follow justice and people's heart but also make sense, otherwise, it is blind loyalty.

The "filial piety" advocated by ancient China is based on the connection of family blood relationship, which is emotional and concrete. "Loyalty" is an extension of "filial piety" in the relationship between people and people outside the family. In terms of logical order, the value of "filial piety" takes precedence over "loyalty". Despite the impact of the revolutionary morality of the 1960s and 1970s, "filial piety" is still a universally respected virtue in contemporary China. Filial piety still plays an irreplaceable role in promoting family relations and social harmony. The tradition of filial piety has not broken in contemporary China.

\section{Conclusions}

As traditional Chinese Confucianism entered Japan as a rational ideology, it collided with the "Japanese spirit" supported by the irrational Shintoism, thus having a profound influence on the inherent culture of Japan. However, the "pragmatic" rationality of the Confucianism "loyalty" has always failed to shake the irrational core of the Japanese Shinto. Instead, it has been absorbed and transformed by Shinto and shows up in the world in the form of Bushido, i.e. the Japanese spirit and quintessence. Because "loyalty", no longer centered at "filial piety", breaks away from the direct empirical objects and the concrete existence of sensibility based on blood ties, it becomes abstract, transcendental, infinite and rigid (lack of flexibility), thus gaining the absolute supreme authority. "Loyalty" becomes the highest value, which, on the one hand, contributes to the national identity of modern Japan. It was once regarded as an important boost for Japan's economic takeoff after World War II and elevated to the height of Max Weber's Protestant Ethics for the development of capitalism. But on the other hand, the religionization and absolutism of "loyalty" is also hidden with the danger of anti-humanity and nationalism. After the Meiji Reform, the authority of the emperor was monopolized. In the Edo period, the limited "loyalty" to the emperor by Confucian Bushido and Hagakure Bushido was replaced by the absolute "loyalty" of the subjects to the emperor. Subsequently, as Japanese imperialists expanded their ambitions and launched foreign aggression, the "loyalty" was misused by militarists. Due to an uproar of propaganda that advocated absolute loyalty to the emperor, many Japanese soldiers sensationally chose to commit suicide by seppuku. This kind of anti-human behavior that goes against modern concepts is closely related to the irrational color of "loyalty", the highest norm of value. In the 1970s, a famous Japanese writer named Mishima Yukio planned hara-kiri meticulously, and his whole set of rituals and the ideas he declared echoed the spiritual purview of the Hagakure Bushido 200 years 
ago, making people vigilant for the possibility that irrationality would be revived in the consciousness of elites and the psychology of the public. To get into the bottom of it, it is hidden in the "shigurui" of the Hagakure Bushido and the irrational Japanese Shintoism.

\section{References}

Han Dongyu. 2004. "The Religionization of Confucianism and The Imperialism of Japan" [J]. Dushu (08).

Inazo Nitobe. 1993. Bushido (Zhang Junyan, Trans.) [M]. Beijing: The Commercial Press (52).

Li Dongjun. 2007. "On Hagakure Kikigaki and Bushido” [J]. Chinese Book Review Monthly (09).

Li Zehou. 2008. On the Psychological Structure of China Culture and Japan Culture // On the Historical Ontology of China Culture and Japan Culture [M]. Beijing: Sanlian Bookstore.

Tang Liguo. 2010. Bushido and Modern Transformation of Japan [M]. Beijing: Beijing Normal University Publishing House.

Yamamoto Tsunetomo. 2014. Hagakure Kikigaki (Zhao Xiujuan, Trans.) [M]. Changchun: Jilin Publishing Group.

Yang Bojun. 2012. Translation and Annotation to The Analects of Confucius [M]. Beijing: Zhonghua Publishing House.

Xunzi. 2012. Translation and Annotation to The Analects of Xunzi (Zhang Jue, Compiled) [M]. Shanghai: Shanghai Classics Publishing House, 183. 
Weiyu Yang, Guangzhou

\title{
The Sequence of Loyalty and Filial Piety and Its Ideological Origins in the Traditional Ethical Culture of China and Japan
}

\begin{abstract}
The traditional ethical culture of Japan is under the influence of Chinese Confucian culture. However, due to differences in historical tradition and social structure, in traditional Japanese culture, "loyalty", as the highest value, is in preference to "filial piety" and it lays a foundation for universal moral principles of the society; while in the Chinese Confucian culture, "filial piety" is regarded as the first and "loyalty" is the natural expansion of "filial piety". The main reason is the influence of the indigenous Shinto in traditional Japanese culture. After the internalization of the indigenous Shinto and the Tennoism as well as the indoctrination of over 600-year ruling of the samurai regime, "loyalty", as the national cultural and psychological heritage, has the religious and irrational mysterious color, which is different from the secularization and the practical rationality of the pre-Qin Confucian ethics of China. Loyalty to the emperor and devotion to public interests advocated by Bushido is an important characteristic of traditional Japanese ethical culture, and the religious and absolute understanding of "loyalty" is hidden with the risk of nationalism and irrationality.
\end{abstract}

Keywords: loyalty; filial piety; Bushido; Confucian Ethics; psychological structure of cultures; Hagakure Kikigaki.

Ethics in Progress (ISSN 2084-9257). Vol. 10 (2019). No. 2, Art. \#13, pp. 155-164.

Creative Commons BY-SA 4.0

DOI:10.14746/eip.2019.2.13 